\section{French science}

\section{Living with budget cuts}

FrENCH research may be facing a budget cut, if the new cost-conscious government of right wing prime minister Jacques Chirac has its way. Late last week, the exact size of the cut had not been officially announced, but sums of the order of FF1,500 million ( $£ 150$ million), or around five per cent of the government civil research and development budget, were being suggested.

Research minister Alain Devaquet was attempting to muster support in the council of ministers for a less damaging attack on his bailiwick, which the powerful minister of state for the economy, finance and privatization, Edouard Balladur, and his colleague for the budget, Alain Juppé, appear to consider a prime target for government savings.

But other fears in the research community seem to be receding. In particular, the prospect that the ministry of research and technology would be dismantled and that the principal research council, the Centre National de la Recherche Scientifique (CNRS), would be weakened, has diminished as the fortunes of some of Chirac's more extreme science and education counsellors has waned.

Devaquet seems to be regarded as a "moderate" by those old-guard science policy makers who have had the chance to meet him, and his senior minister (Devaquet is "délégué" to the minister of education, René Monory) has even embraced some of the policies of his reforming socialist predecessor, Jean-Pierre Chevènement. Moreover, Monory's second-in-command, the more zealous Michèle Alliot-Marie, appears for the time being to have been put firmly in a more junior role. Another Chirac zealot, the medical scientist Gerard Milhaud, has sofar been given no important post.

Devaquet's own powers and responsibilities were finally clarified last Friday. The ministry of research and technology will survive (in a somewhat truncated form) as the ministry of research and higher education, and there will be no "third tier" in the form of a prime ministerial office for research allocating budgets, as Milhaud and Alliot-Marie had been recommending. Thus for science, the buck will stop with Devaquet; but his ministry has lost control of a good deal of technology policy which has returned to the ministry of industry.

Devaquet's ministry nevertheless retains full budgetary control of the medical and agricultural research councils INSERM and INRA, against the initial advice of Chirac's radicals, and of ANVAR, the agency whose job is to find commercial applications for French academic research. Devaquet will, as expect- ed, have full control of CNRS and of university research, which are no longer to be separate. Unlike his predecessor, however, the new research minister has lost control and finance for the whole industrial side of the atomic energy agency (CEA), the space agency (CNES), the agency for alternative energy and conservation (AFME), the telecommunications research agency CNET and the new $£ 400$ million science exploratorium, La Villette (except for fundamental sciences).

It is clear that policies on science and technology are being assiduously separated, which is expected of a government that believes in non-intervention in industrial affairs but which runs against the recently published advice of the high scientific advisory council to the ministry of research, the Conseil Supérieure de la Recherche et de la Technologie.

Another danger for science may be represented by the threatened budget cut, which is one of the largest parts of a FF10,000 million ( $£ 1,000$ million) saving in overall government spending promised by the new Prime Minister. Research alone is clearly more vulnerable than research in a package including industrial development, and the previous government's 1986 budget for research does stand high above the parapet, with a 4-5 per cent real growth previously planned against zeros in most other ministries. The likely cuts would wipe out this increase, while last week's eight per cent devaluation of the franc against the deutschsmark may take the real cut even deeper.

Robert Walgate

\title{
Teacher/student conflicts
}

New York

THE American Chemical Society (ACS) is making a serious effort to regulate the disputes that may arise between academic researchers and institutions and the students who work in them on doctoral and other research programmes. The society is preparing a report on academic authorship arising from collaboration between faculty and graduate students. At the society's spring meeting last week, the ACS copyright committee discussed some of the ways in which disputes over copyright might be avoided.

This potentially contentious issue has hitherto attracted little attention from most scientific societies. On most college campuses, the copyright question is ethical rather than legal. Copyright law clearly considers any written work the sole property of the author, which reflects the liberal arts tradition that a research paper is an individual endeavour. But some researchers in the sciences contend that regardless of their involvement in the writing of a research report, their contributions in terms of experience, expertise and especially equipment merit co-authorship.

One ACS member wryly encapsulated his response to the graduate student who would remain independent: "Go get your beakers, go get your test tubes, purchase your NMR, then come back to me with your thesis - in 20 years". A student's contribution to his professor's paper is even more difficult to assess.

Based on responses from the deans of several prominent US graduate schools, the ACS committee has concluded that authorship abuses are infrequent, but suggests that professors and graduate students should outline their expectations in written agreements before beginning a re- search project. Such measures will not necessarily bring about standard criteria for authorship. Frank Perkins, dean of the Massachusetts Institute of Technology's graduate school, thinks "there are a lot of graduate students who are troubled by the fact that some professors give them more credit than others" for the same contributions. He also points out that doctoral candidates may be reluctant to register formal complaints against their supervisors, since the complaints could easily boomerang.

The changing face of academic authorship first caught the spotlight last fall in a letter from Stanford University president Donald Kennedy to council members of the American Association of Universities (AAU). Citing an increased incidence of disputes between faculty members and students over credit for collaborative work, Kennedy called for "systematic discussion" of "the allocation of responsibility and credit for scholarly work", and of the forces that are driving research "towards a level of complexity at which it becomes difficult to determine responsibility of authorship".

AAU says the discussion Kennedy had hoped to provoke has not ensued. Neither have the courts hammered out precedents for copyrighting academic work, primarily because lucrative benefits have not been at stake. But a new kind of academic dissertation may soon change all that. Computer software developed by degree candidates can bring rewards more tangible than academic distinction, and could become a point of copyright contention. As software authorship becomes a matter of business, court decisions defining law may well set standards for academic authorship in general.
Karen Wright 